PONTIFÍCIA UNIVERSIDADE CATÓLICA DO RIO DE JANEIRO

Habib's: a estratégia empresarial por trás da esfiha de $R \mathbf{\$ 1 , 2 0}$

\author{
Illan Stern
}

Trabalho de Conclusão de Curso

Centro de CIÊnCIAS SOCIAIS - CCS

DePARTAMENTO de AdMINISTRAÇÃo

Graduação em Administração de Empresas 
Illan Stern

Habib's: a estratégia empresarial por trás da esfiha de $\mathbf{R} \$ 1,20$

Trabalho de Conclusão de Curso

Trabalho de Conclusão de Curso, apresentado ao programa de graduação em Administração da PUC-Rio como requisito parcial para a obtenção do título de graduação em Administração.

Orientador: Fabio de Paula

Rio de Janeiro

Novembrode 2019. 


\section{Agradecimentos}

Gostaria de agradecer primeiramente aos meus pais e familiares por terem me dado a oportunidade de estudar na PUC-Rio, uma das melhores faculdades do Brasil. Aos meus amigos por compartilharem diversos momentos importantes durante essa trajetória.

Ao meu orientador, Fábio de Oliveira Paula, por me ajudar nesta etapa tão importante. A todos os professores que contribuíram com minha formação, experiência e momentos compartilhados que me tornaram uma pessoa melhor e com mais conhecimento. Obrigado. 


\section{RESUMO}

STERN, Illan. Habib's: a estratégia empresarial por trás da esfiha de R\$1,20. Rio de Janeiro, 2019. 46p. Trabalho de Conclusão de Curso Departamento de Administração. Pontifícia Universidade Católica do Rio de Janeiro.

O Habib's consegue oferecer, ao consumidor final, preços acessíveis, mantendo a qualidade dos produtos. O objetivo deste trabalho é entender como a empresa conseguiu manter a liderança em custo, mostrando também como foi o processo de integração vertical realizado ao longo dos anos. Os conceitos utilizados tratam temas como Tripologia de Porter, Integração Vertical e Estratégia. Foi feita uma pesquisa exploratória através da seleção de sujeitos com experiência neste mercado para responderem um questionário, e os dados foram analisados e interpretados pelo autor. O projeto apresenta um maior entendimento sobre como a organização conquistou uma grande parcela do mercado, a partir da estratégia traçada e os efeitos desta tomada de decisão.

Palavras-chave: Habib`s; Liderança em Custo; Integração Vertical; 


\section{ABSTRACT}

STERN, Illan.Habib's: the business strategy behind the $R \boldsymbol{R} \mathbf{1 . 2 0}$

“esfiha".Rio de Janeiro, 2019. 46p. Trabalho de Conclusão de Curso Departamento de Administração. PontifíciaUniversidadeCatólica do Rio de Janeiro.

Habib's is able to offer the consumer affordable prices while maintaining the quality of the products. The objective of this project is to understand how the company was able to maintain the leadership in cost, also showing how was the process of vertical integration. The concepts used deal with themes such as Porter's Tripology, Vertical Integration and Strategy. An exploratory research was made through the selection of subjects with experience in this market to answer a questionnaire, and the data were analyzed and interpreted by the author. The project has an understanding of how the organization conquered market-share, from the strategy outlined and the effects of this decision making.

Palavras-chave: Habib’s; Leadership in Cost; Vertical Integration; 


\section{SUMÁRIO}

1. INTRODUÇÃ

1.1. Contextualização ……………………………………………………....

1.2. Objetivo Principal ……………………………………………………..... 15

1.3. Objetivos secundários ............................................................................. 15

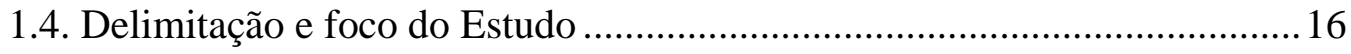

1.5. Relevância do Estudo .................................................................................... 16

2. REFERENCIAL TEÓRICO ............................................................................17

2.1. Estratégia.......................................................................................... 17

2.1.1. Vantagem Competitiva ………………………………………...... 18

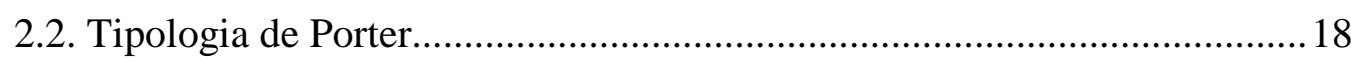

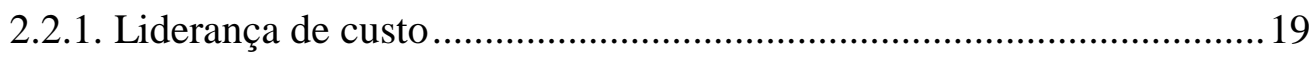

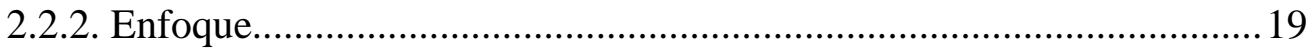

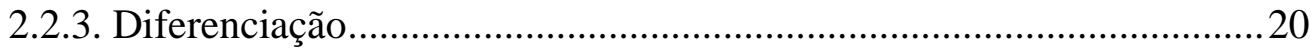

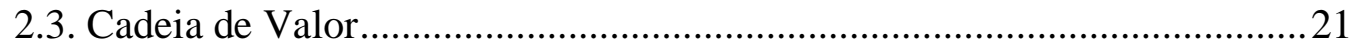

2.4. Integração Vertical .............................................................................. 21

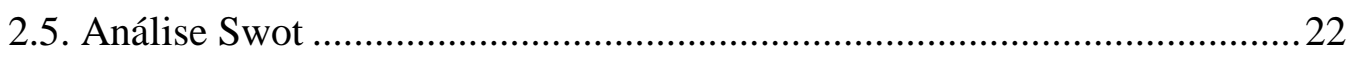

2.5.1. Análise do Ambiente Interno................................................................23

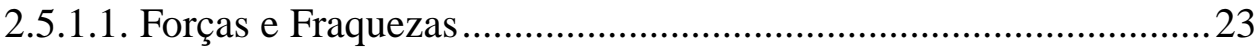

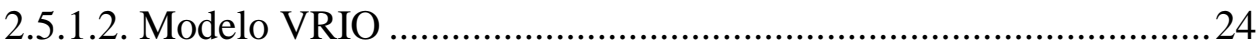

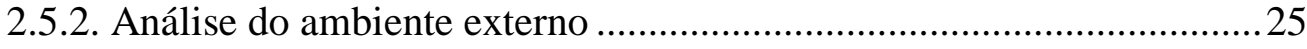

2.5.2.1. Oportunidades e Ameaças ..............................................................26

2.5.2.2. 5 Forças de Porter ......................................................................26

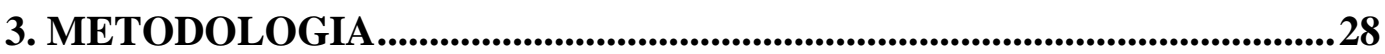

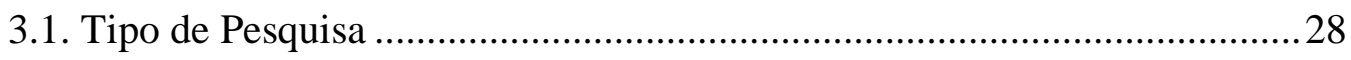

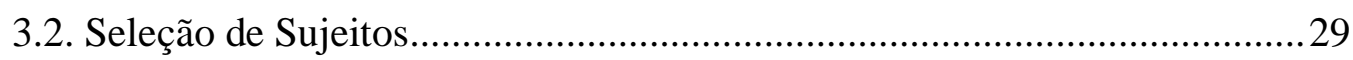

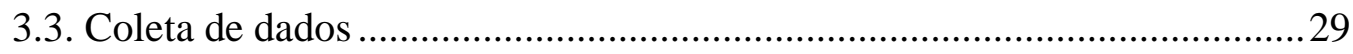

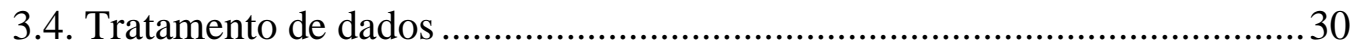

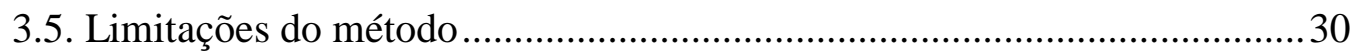

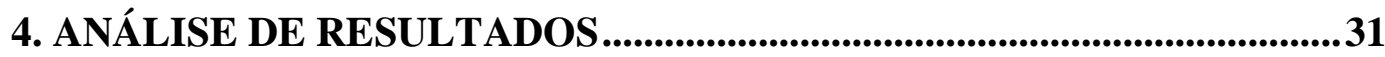

4.1. Análise Ambiental................................................................................... 


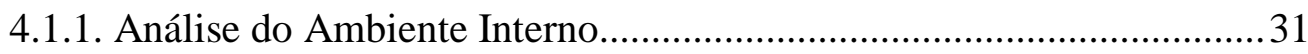

4.1.2. Forças e Fraquezas ........................................................................... 31

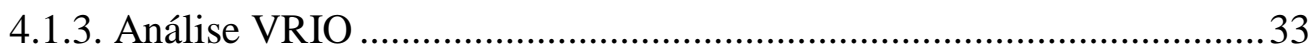

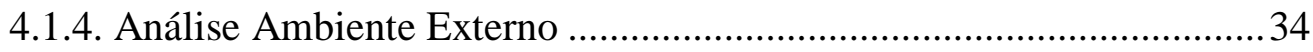

4.1.5. Oportunidades e Ameaças ........................................................................ 34

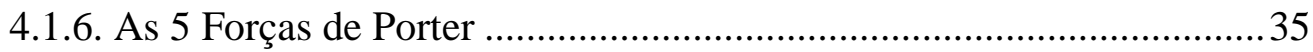

4.2. Estratégia de Liderança de Custo e Integração Vertical ............................. 37

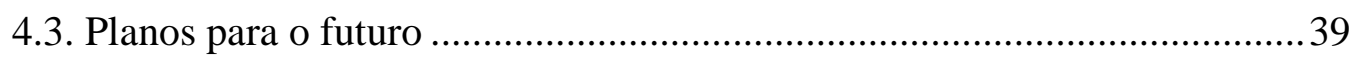

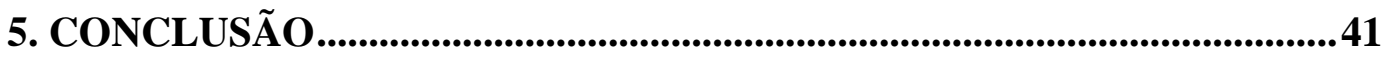

5.1. Sugestões e recomendações para novos estudos .......................................41

REFERÊNCIAS BIBLIOGRÁFICAS ...............................................................43

ANEXO 1: ROTEIRO PARA AS ENTREVISTAS ...........................................45 


\section{LISTA DE FIGURAS}

Figura 1: Participação de alimentação fora do lar ...............................................9

Figura 2: Porcentagem de despesa com alimentação fora do lar nas regiões brasileiras ...................................................................................................................10

Figura 3: Principais locais de consumo alimentar fora de casa.................................11

Figura 4: Market-Share do setor de comida rápida até 2016...................................12

Figura 5: Evolução Layout da marca.................................................................................14

Figura 6: Modelo VRIO e suas questões chave.......................................................25

Figura 7: Proposta de avaliação dos recursos .........................................................25

Figura 8: strutura verticalizada da empresa e características .................................38

Figura 9: Próximos passos da organização..............................................................40 


\section{LISTA DE TABELAS}

Tabela 1: Perfil dos profissionais entrevistados .........................................................29

Tabela 2: Análise dos recursos empresariais sob a perspectiva da Análise VRIO 


\section{INTRODUÇÃO}

\subsection{Contextualização}

A maneira como nos alimentamos vem sofrendo transformações ao longo do tempo. Isso devido a efeitos da globalização, da entrada da mulher no mercado de trabalho, criação de novas tecnologias e um marketing cada vez mais direcionado e eficaz no seu convencimento. Nessa perspectiva, como mostra a figura abaixo, observa-se que a população mundial modificou seu comportamento alimentar, comendo com mais frequência em estabelecimentos comerciais e gastando mais de sua renda mensal nesse tópico.

Em relação a esse fato, segundo Liu (et al., 2013):

Nos Estados Unidos, por exemplo, em 2010, a parcela dos gastos com alimentação fora do domicílio atingiu o nível de $49 \%$ do total dos dispêndios com alimentação. Em Taiwan, os gastos com alimentação fora do domicílio saltaram de 6\% para $26 \%$ do total despedido com alimentação entre 1983 e 2000. Na China, essa parcela variou de 5,0\% do total dos dispêndios com alimentação, em 1992, para 14,7\% em 2000.

\section{UM APETITE MAIOR POR COMIDA FORA DE CASA}

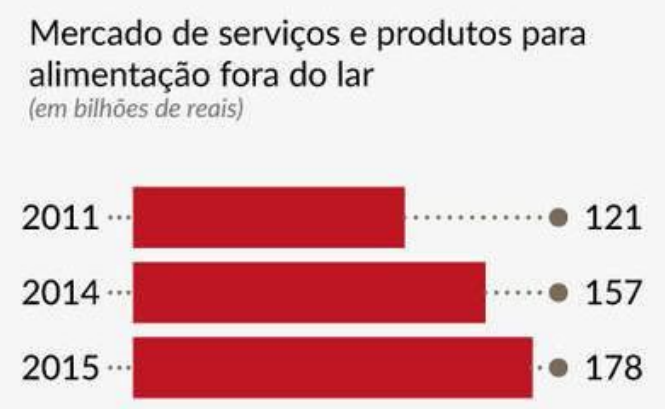
Participação do setor nos gastos das
famílias com alimentação (em \%)
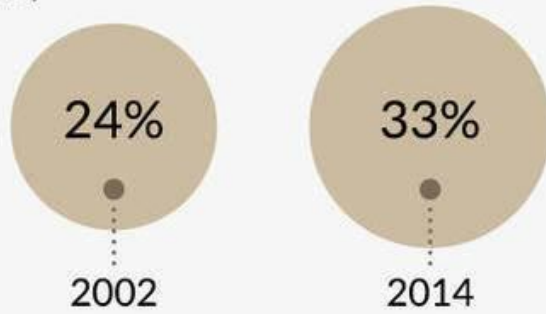

Nos Estados Unidos, o gasto com produtos para alimentação fora do lar representa $49 \%$ das despesas familiares com comida

Fontes: GS\&MD e Instituto Foodservice Brasil

Figura 1: Participação de alimentação fora do lar.

Fonte: GS\&MD e Instituto Foodservice Brasil. 
Em terras brasileiras também notamos essa variação. Nesse sentido, houve um grande aumento no consumo de alimentos "na rua", os quais oferecem maior praticidade e mais tempo para realizar outros afazeres, tendo em vista o novo estilo de vida da nossa população. Dessa forma, de acordo com a pesquisa realizada pelo IBGE (2010):

Os gastos com alimentação fora do domicílio vêm aumentando nos últimos anos. Os dados da última Pesquisa de Orçamentos Familiares (POF), de 2008-2009, mostram que a despesa mensal com alimentação fora do domicílio teve participação de $31,1 \%$ nos gastos mensais com consumo alimentar. Essa parcela era de $24,1 \%$ segundo a POF de 2002-2003, aumentando cerca de 30\% durante o período entre as duas pesquisas.

\section{Porcentagem de despesa com alimentação fora de casa nas regiões do Brasil}

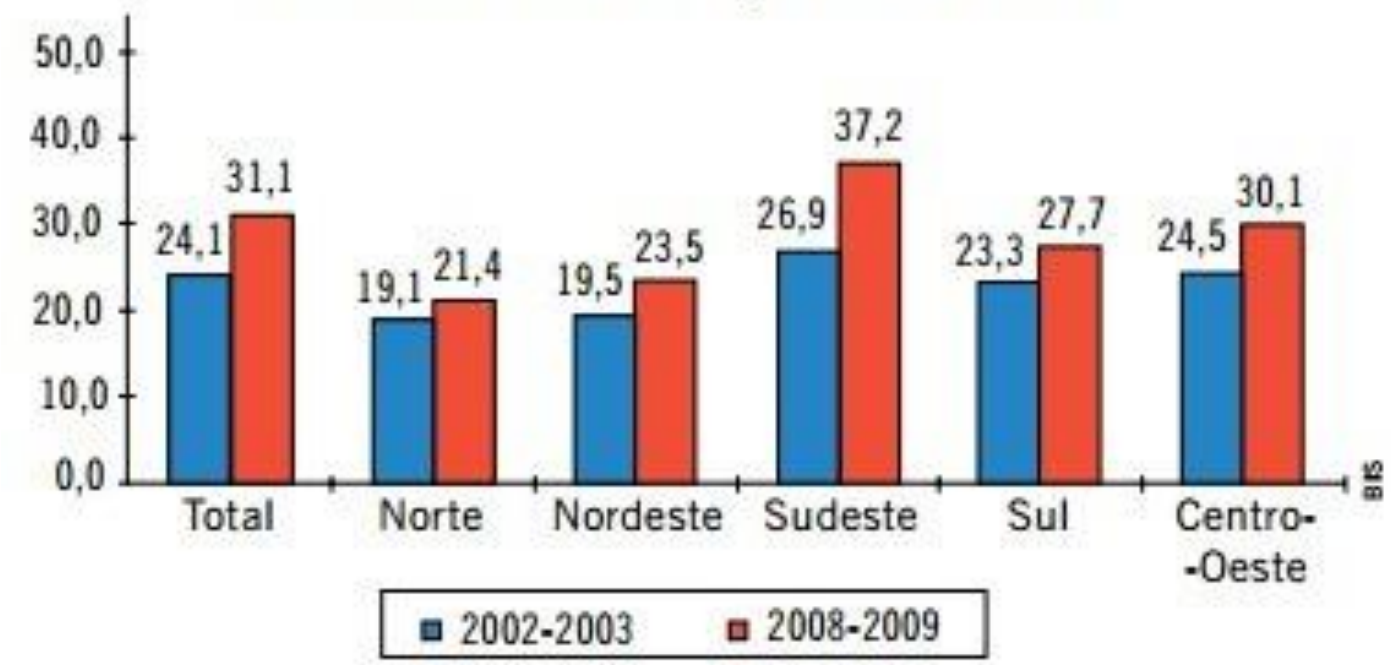

Figura 2: Porcentagem de despesa com alimentação fora do lar nas regiões brasileiras. Fonte: IBGE.

Esse novo cenário enfatiza a mudança de hábitos dos brasileiros e cria uma expectativa grande para comerciantes do ramo alimentício que investem na busca desses novos consumidores. Em relação a esse fato, notamos que o gosto dos brasileiros é variado e as diferentes parcelas da sociedade consomem comidas distintas, levando em consideração: preço, agilidade, sabor e desejos individuais.

Tais critérios são exemplificados na figura abaixo, demonstrando os principais locais onde os consumidores costumam fazer refeições fora de casa, em solo brasileiro. Dessa maneira, nota-se que o apreço popular pela comida a quilo a 
é maior, seguida pela comida rápida, pelo restaurante a La carte, por bares, padarias e ambulantes.

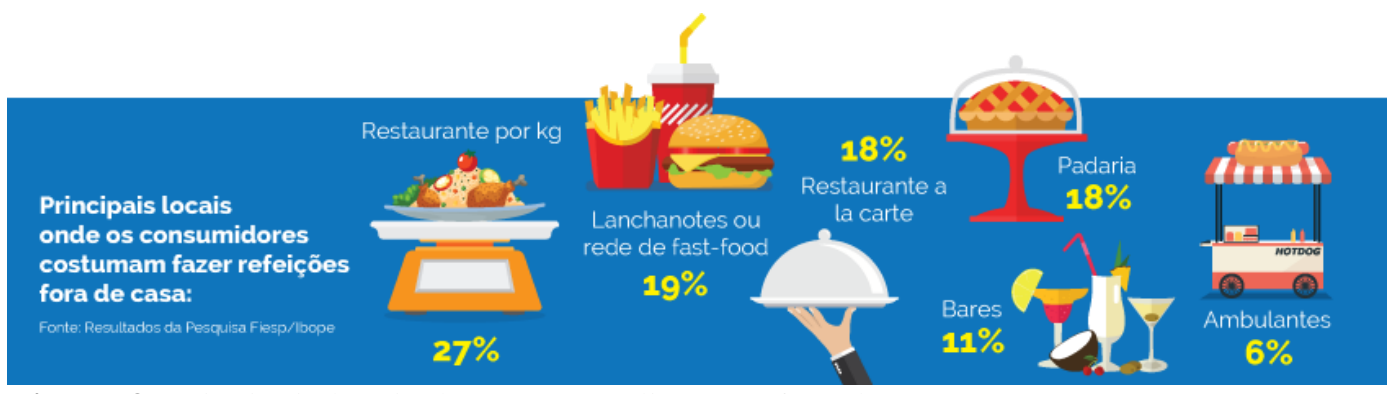

Figura 3: Principais locais de consumo alimentar fora de casa.

Fonte: Ibope.

Em relação ao Fast-Food brasileiro podemos notar que é um ambiente concorrido, repleto de variedades e com grandes marcas multinacionais competindo pelo Market-Share. Nessa perspectiva, Mc Donald's, Burger King, Habib’s, Ragazzo, Bob`s, KFC, Pizza Hut, Subway, Popeyes, Taco Bell, Spoleto, Domino’s, e outras empresas menores compõem o mercado de comida rápida investindo cada vez mais em oferecer ao consumidor uma comida de qualidade, ao menor preço possível e com muita agilidade.

Quanto ao Mc Donald`s, Burger King e Bob’s, estamos vivenciando a época da "guerra dos hamburgeres". Tais competidores reduzem os preços dos principais produtos, progressivamente, a fim de atrair e captar novos clientes e por consequência aumentar sua parcela de preferência de produto e por marca no consumidor final. Nessa disputa, nota-se que o Burger King ameaça seu principal concorrente e cresce em relação à escolha do freguês, como sendo enfatizado na figura a seguir. 


\section{O Rei e o Palhaço}

\section{Burger King toma ano a ano espaço do McDonald's}

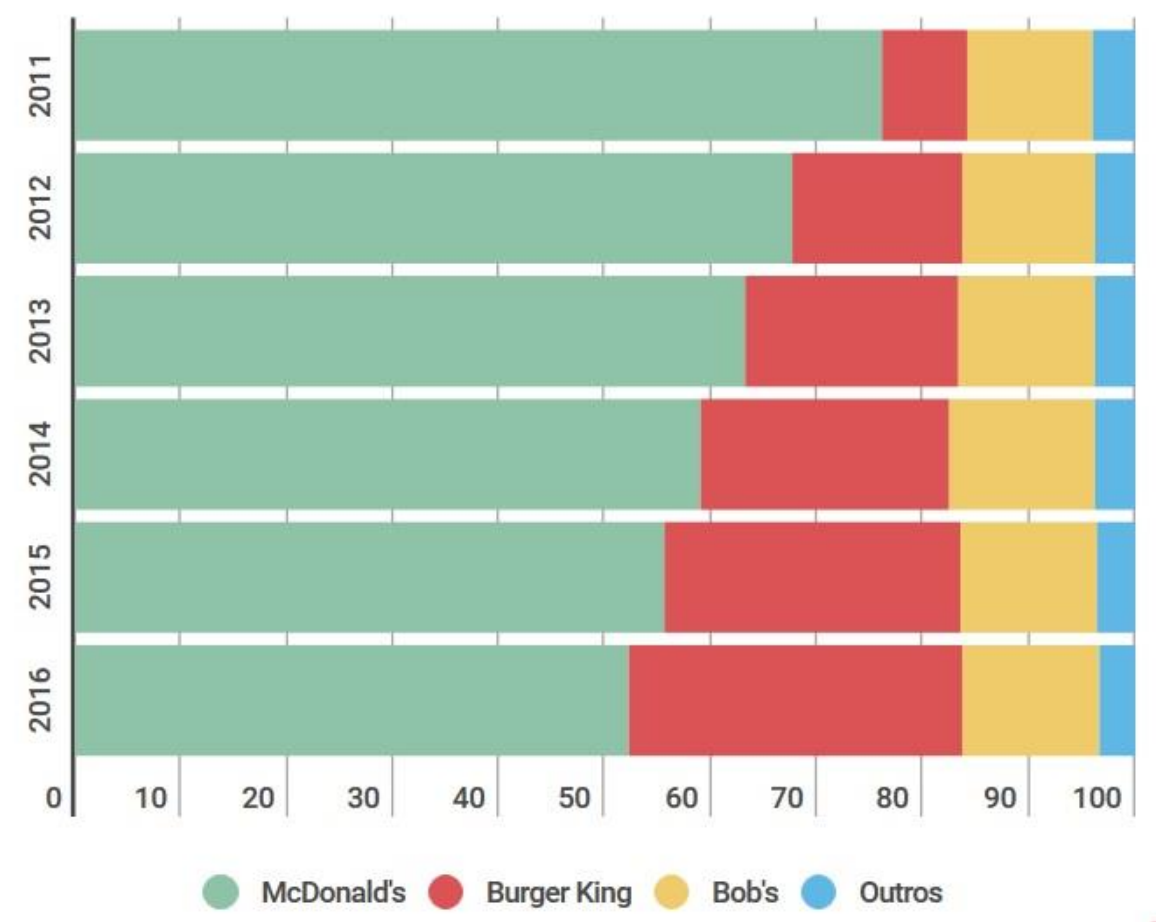

Figura 4: Market-Share do setor de comida rápida até 2016.

Fonte: Empiricus Research.

Em paralelo, o Habib’stem caminhado a passos largos para enfrentar seus concorrentes, oferecendo um preço de promoção mais agressivo, mantendo a qualidade do produto e visando gerar uma boa experiência de consumo para o comprador. Enquanto as principais multinacionais comercializam suas "ofertas do dia” a R\$5,00 (Burger King) e R \$7,90 (Mc Donald's), a empresa brasileira cobra $\mathrm{R} \$ 1,20$ pela esfiha da promoçao, principal produto da rede. Nessa perspectiva, a percepção de valor e custo-benefício do consumidor cresce, uma vez que o mesmo poderá se alimentar mais com o mesmo valor gasto nos outros estabelecimentos. Por consequência, a empresa vem conquistando o "bolso" e a preferência do mercado de comida rápida e ganhando cada vez mais uma parcela do mercado. 
Desde a inauguração da primeira loja em 1988, localizada em São Paulo, o fundador do grupo Alberto Saraiva não imaginaria a proporção que o modelo de preços baixos com qualidade, que foi adotado pela empresa, resultaria na criação da maior cadeia de restaurantes fast-food fundada em solos brasileiros e da maior rede de culinária árabe do mundo.

Para conseguir tal proeza, o criador da marca precisou implementar algumas estratégias diferenciadas, tanto para criação de marca, quanto para a estrutura empresarial que resultaram em uma crescente ascensão na abertura de novos negócios e na busca por uma parcela maior do Market-share.

Em relação a estrutura da empresa, foram desenvolvidas 14 fábricas industriais que auxiliam no abastecimento das lojas e na manutenção do padrão da rede, uma central de atendimento telefônico chamada Voxline, ajudando a manter o delivery eficaz e eficiente, abertura de lojas por meio do sistema de franquias e a instituição do "Alô Tia Eda", segmento da empresa responsável por cuidar do Serviço de Atendimento ao Cliente.

Além disso, foi montado um Escritório Central em São Paulo, em que foi formado uma sólida equipe por trás, da própria franqueadora, composta por diferentes equipes que auxiliam o dia-a-dia de lojas pertencentes a rede e franqueados da marca. Nessa perspectiva, são áreas de Operações, Marketing, Qualidade, Novos Produtos, Expansão, Financeiro, Logística e Recursos Humanos que trabalham diariamente com o intuito de elevar a lucratividade da empresa e gerar uma boa experiência de consumo ao consumidor final.

No âmbito operacional, a empresa se desenvolveu para apoiar suas lojas. Dessa maneira, conta com duas iniciativas que promovem a melhoria do conhecimento e do apoio aos lojistas e colaboradores. Nesse prisma, a primeira é a Universidade Habib's, a qual proporciona aos colaboradores da marca um desenvolvimento progressivo em assuntos como gestão e formação de líderes, desenvolvimento humano e atividades da rede. A segunda é a UTIH, Unidade de Tratamento Intensivo do Habib's, entidade que auxilia franqueados que não estão passando por bons momentos, por um período de 45 dias, em que gestor da franqueadora analisa os pontos que interferem diretamente na operação e no resultado, para assim serem tratados e resolvidos. 
Em relação ao cardápio, a primeira loja foi inaugurada ofertando apenas esfihas, kibes e charutinhos. Com o passar do tempo, foram implementados produtos mais comuns ao paladar brasileiro, tais como pizzas, pastéis e bebidas alcoólicas. Anos depois foram adicionados batatas fritas, refrigerantes, diferentes sabores de esfihas e sobremesas. Em um passado mais recente foram incorporados no cardápio os minikibes, bolinho de bacalhau e pratos de almoço com comida para todos os gostos. Nessa perspectiva, nota-se que a estratégia da rede é oferecer uma ampla variedade de produtos no cardápio, satisfazendo os diferentes gostos do público brasileiro e atraindo cada vez mais pessoas para o consumo dentro de loja.

Com relação à da identidade visual da marca, pode-se notar que sofreu algumas transformações ao longo dos anos. Nesse âmbito, em 2013 a marca reconfigurou por completo seu logotipo, simplificando-o e trocou a cor amarela pelo vermelho vibrante, como podemos ver nas imagens abaixo:

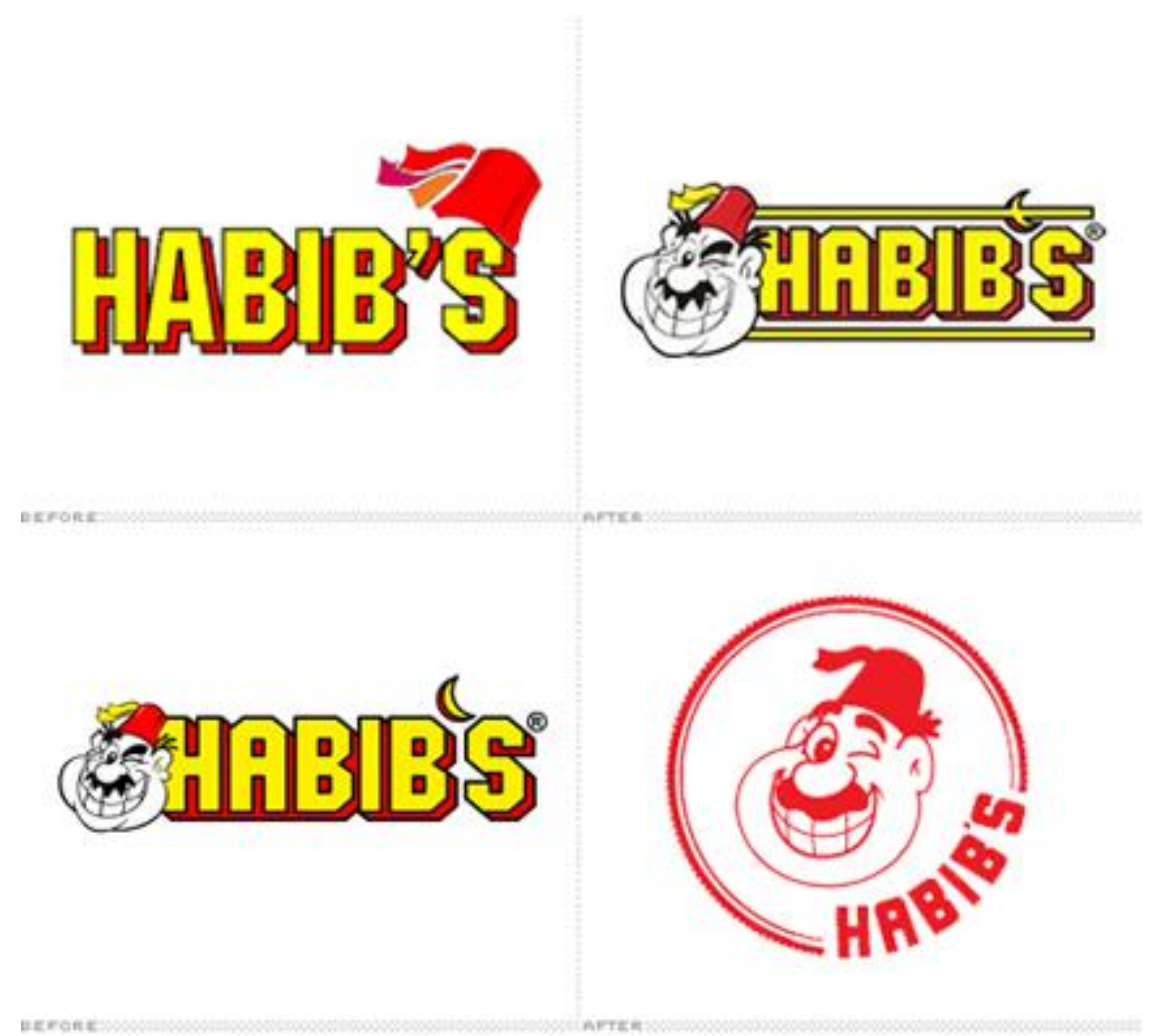

Figura 5: Evolução Layout da marca.

Fonte: Empresa Habib’s. 
Levando em consideração tal concorrência e a disputa acirrada por clientes através de preço e propaganda, chega-se ao questionamento: Como o Habib's consegue entregar preços mais baratos do que a concorrência ao cliente final, ao longo do tempo, reforçando a estratégia de ser uma marca de baixo custo, mantendo a qualidade e alcançando uma parcela cada vez maior do mercado?

\subsection{Objetivo Principal}

A partir de uma estratégia agressiva baseada na oferta de produtos a um valor baixo, a empresa Habib’s combinou preços competitivos, conservando a qualidade dos produtos e por consequência sendo vista como uma marca de bom custobenefício para o consumidor final. Tal estratégia gerou no mercado uma nova tática de gestão e posicionamento de marca, sendo identificadas em outras empresas, de diversos setores, tais como a rede de Hotéis Íbis, Gol Linhas Aéreas, Casas Bahia no cenário brasileiro.

Este trabalho tem como propósito principal a análise e estudo dos meios utilizados pelo Habib’s para conseguir manter a estratégia de liderança em custo e do principal produto comercializado custando um preço bem abaixo do que a média dos outros restaurantes fast-food, ganhando cada vez mais o apelo do consumidor final e uma parcela maior do mercado alimentício de comida rápida.

\subsection{Objetivos secundários}

- Entender como a estratégia de liderança em custo (Porter, 1983), utilizada pela firma gera vantagem competitiva em relação aos concorrentes e como a organização atua em cima desse fator diferencial.

- Compreender como a companhia a busca o melhor plano de comunicação ao cliente, ressaltando sua liderança em custo e gerando o menor custo ao cliente final.

- Analisar os meios utilizados pela empresa para a atração, apelo e manutenção dos clientes. 
- Estudar os motivos que levam uma empresa a integralizar verticalmente (Barney; Hersterly, 1990) para trás, e o que tal modelo pode agregar de valor.

\subsection{Delimitação e foco do Estudo}

A análise contempla o estudo do case de sucesso da empresa Habib’s desde

1988, até os dias atuais, analisando como a empresa conseguiu triunfo a partir de uma formulação de uma estratégia baseada em preços baixos, produzindo seus próprios insumos e comprando em uma grande escala, a nível Brasil. Nota-se que, vai explorar também as firmas que foram criadas e adquiridas pela organização dentro da estratégia de integração vertical para trás, entendendo como ocorreu e se desenvolveu o processo em estudo, para que a oferta de insumos abastecesse a grande demanda da rede de lojas.

\subsection{Relevância do Estudo}

O conteúdo se faz relevante para organizações do setor de restaurantes, mais especificamente de fast-foods, mas também, de diferentes segmentos que desejam oferecer ao seu consumidor um serviço de qualidade, a um preço mais acessível, focando em quais medidas podem ser tomadas para abaixar o custo sem perder sua identidade e qualidade.

Além disso, o conhecimento apresentado neste trabalho poderá auxiliar empreendedores a formular estratégias inovadoras em seus empreendimentos e pode ajudar na tomada de decisão de um novo plano a ser seguido, concretizando como empresas que já obtiveram sucesso no passado podem servir de exemplo para startups em formação.

Em relação a firmas e empreendedores que já verticalizaram para trás, conseguindo controlar custos e oferecendo um bom produto, a um preço baixo, cabe o aprendizado de como o Habib's conseguiu realizar tal feito com sucesso por tanto tempo, se perpetuando como uma grande marca do fast-food brasileiro. 


\section{REFERENCIAL TEÓRICO}

Nesta parte do trabalho são abordados conceitos teóricos associados ao assunto principal que servirão de base para a análise realizada. Nessa perspectiva, o trabalho vai investigar e trabalhar conceitos estratégicos e de marketing relacionados ao setor alimentício, mais precisamente a franqueadora Habib`s.

\subsection{Estratégia}

A estratégia bem formulada é imprescindível para o futuro das organizações, uma vez que definem os caminhos que a empresa vai adotar e são fundamentais para o sucesso. A estratégia é mais do que a aspiração de crescer como empresa e difere da missão e valores. A mesma estabelece seu posicionamento de negócio e seus objetivos.

Segundo Thompson (2007). "É o plano da gestão para fazer crescer o negócio, atrair e deixar satisfeitos os clientes, competir com sucesso, conduzir as operações, e atingir determinados objetivos de desempenho organizacional".

De acordo com Daft (2003), estratégia:

É o plano de ação que determina a alocação de recursos e outras atividades que ajudam a organização a atingir os seus objetivos. A estratégia centra-se nas "competências centrais", no desenvolvimento de sinergias e em criar valor para os clientes.

Nessa perspectiva, o processo estratégico é o suporte para que se concretize a vantagem competitiva da empresa, uma vez que é analisado o ambiente externo e interno da empresa. Dessa forma, é formulado um estudo sobre as forças, fraquezas, oportunidades e ameaças da empresa em comparação ao mercado e concorrentes. Também é estudada a relação da organização com os seus recursos principais, investigando se os mesmos são valiosos, raros, difíceis de imitar e se a organização explora bem tal "patrimônio". 
Somente assim, de acordo com Porter (1980), “a estratégia é um conjunto de escolhas de longo prazo que uma organização faz para se distinguir de seus concorrentes, buscando criar as vantagens competitivas em que ela estará baseada".

\subsubsection{Vantagem Competitiva}

A vantagem competitiva é uma vantagem que a empresa possui em relação à empresa concorrente e possui atributos que possibilitam tal vantagem. A otimização de processos e capacidade técnica são exemplos de vantagem competitiva que uma empresa pode dominar para não ser superada pelos concorrentes.

Uma vantagem competitiva sustentável ou sustentada ocorre quando uma empresa implementa uma estratégia de criação de valor da qual outras empresas são incapazes de duplicar os benefícios ou os mesmos são custosos de imitar. (Hitt et al., 1999).

Nesse prisma, a empresa que utiliza de forma eficiente seus recursos e se destaca por esse fato em relação a concorrência, enfatizando dessa forma que a vantagem competitiva é oriunda de um bom uso de recurso em comparação a outros que não conseguem explorar tão bem, da maneira como gostariam.

De acordo com Porter (1985):

Vantagem competitiva surge, fundamentalmente, do valor que uma empresa é capaz de criar para seus compradores, valor este que excede o custo da empresa em criálo. Valor é o que os compradores estão dispostos a pagar, e valor superior provém da oferta de preços inferiores aos dos concorrentes para benefícios equivalentes ou o fornecimento de benefícios únicos que mais do que compensam um preço superior. Existem dois tipos básicos de vantagem competitiva: liderança de custos e diferenciação.

\subsection{Tipologia de Porter}

Para Porter (2004), uma estratégia competitiva é a medida que a organização procura a fim de ajustar-se ao ambiente externo. 


\title{
2.2.1. Liderança de custo
}

\author{
Conforme Porter (1986):
}

Liderança no custo total é obtida através da capacidade de a empresa fazer com o seu custo seja inferior ao dos concorrentes. Através de produção padronizada, escala, minimização e controle das despesas gerais, sem, contudo, comprometer a qualidade dos produtos e serviços.

A estratégia de Liderança de Custo ocorre a partir do momento em que a organização controla seus custos, lançando seus produtos mais baratos do que os seus concorrentes, no intuito de ganhar cada vez mais Market-share.

Ademais, segundo Porter (1986):

Liderança no custo total é obtida através da capacidade de a empresa fazer com o seu custo seja inferior ao dos concorrentes. Através de produção padronizada, escala, minimização e controle das despesas gerais, sem, contudo, comprometer a qualidade dos produtos e serviços. Esta estratégia é mais adequada quando a demanda do público atendido é sensível a preço. Nesta estratégia a empresa continua obtendo lucros mesmo quando seus concorrentes já tiveram os seus lucros consumidos pela competição.

Sendo assim, com o andamento de tal estratégia, as empresas se importam em produzir com o intuito de ganhar mercado por conta do preço, satisfazendo os clientes que comprarem, não se preocupando tanto com diferenciação e enfoque.

A estratégia de Liderança no Custo total persegue uma rigorosa redução de custos buscando em relação aos concorrentes baixo custo, não se esquecendo da qualidade e assistência que estão vinculados aos produtos. A estratégia relacionada ao baixo custo proporciona uma posição favorável frente ao mercado, porém colocar em prática esta estratégia exige investimento em equipamento, preço fixo e alta parcela de mercado. (Porter, 2004).

\subsubsection{Enfoque}

A estratégia de enfoque procura centralizar as forças em um grupo específico de compradores, ou em uma determinada área geográfica, portanto o enfoque pode ocorrer de formas variadas. As estratégias de custo baixo e diferenciação aplicamse com ampla abrangência em todo o setor, diferentemente da estratégia de enfoque que procura atender um alvo específico com alta eficiência. A empresa compreende 
que é possível atender as necessidades de um público-alvo mais específico (Piscopo; Oliveira Jr., 2003).

A estratégia representa a observação de possíveis clientes, mercado-alvo ou uma linha de produtos, produzindo e entregando melhor do que os concorrentes com o intuito de satisfaze-los e consequentemente fidelizar tal grupo de pessoas.

Para Silva (2003):

O enfoque consiste em centralizar num determinado grupo comprador, ou num segmento de linha de produtos, ou em mercado geográfico. Esta estratégia possui a premissa de atender um alvo estreito mais efetivo ou eficientemente do que os concorrentes que estão competindo de forma mais ampla. Consequentemente a empresa atinge a diferenciação por satisfazer melhor as necessidades de seu alvo particular, ou custos mais baixos na obtenção deste alvo, ou ambos.

\subsubsection{Diferenciação}

A estratégia de diferenciação distingue a oferta da empresa das ofertas dos concorrentes pela criação de um diferencial competitivo. Esta estratégia não considera grandes volumes e preço baixo. Ao contrário, a estratégia de diferenciação tem a finalidade de atender um número menor de clientes de uma forma mais personalizada, o que inviabiliza a conquista de grande participação de mercado. Desta forma, a empresa cria barreiras de entrada aos concorrentes em virtude da lealdade obtida dos consumidores. O poder de barganha dos compradores reduz à medida que diminui a sua sensibilidade ao preço e também por causa da escassez de opções que atendam satisfatoriamente as suas necessidades (Piscopo; Oliveira Jr., 2003).

Tal estratégia procura estabelecer produtos e serviços diferenciados e que não são encontrados tão facilmente nos concorrentes. Isso pode ser feito por diferentes maneiras. Entretanto, esse plano não é focado em custos, podendo ter preços mais altos.

Segundo Porter (2004):

A diferenciação alavanca uma margem superior em relação aos produtos, o que ocasiona a exclusão de uma posição de baixo custo". Ademais, o autor também expressou que "diferenciação é uma estratégia viável que permite obter retornos acima da média, pois ela possibilita enfrentar as cinco forças competitivas, embora de um modo diferente do que na liderança de custo. 


\subsection{Cadeia de Valor}

Para Hansen e Mowen (2001), é um "conjunto de elos de ligação das atividades de criação de valor da matéria-prima básica até o descarte do produto acabado pelo usuário final". Desta forma, todos os elementos que são envolvidos dentro de uma organização estabeleçam o valor do produto ou serviço para o cliente final.

Os elementos básicos que formam uma cadeia de valor são as atividades primarias (logística interna, operações, logística externa, marketing e vendas) e as atividades de apoio (aquisição, desenvolvimento de tecnologia, gerencia de recursos humanos e infra-estrutura). Tais atividades de valor são interdependentes, sendo assim, o bom gerenciamento dessa cadeia pode resultar em um diferencial competitivo e um comprometimento com os clientes.

Sendo assim, para Porter (1986):

Cadeia de valor de uma empresa e o modo como ela executa atividades individuais são um reflexo de sua história, de sua estratégia, de seu método de implementação de sua estratégia, e da economia básica das próprias atividades.

Nessa perspectiva, as uniões de todos os elementos envolvidos em uma organização geram para o cliente final o valor do bem ou serviço. Dessa forma, uma harmonia entre processos, recursos e eficiência operacional concretizam a forma como a empresa é percebida no mercado e como isso pode ser aproveitado.

Ademais, Shank e Govindarajan (1997) enfatizam que:

Uma empresa pode aumentar sua lucratividade não apenas compreendendo sua cadeia de valor - do projeto à distribuição - mas também compreendendo como as atividades de valor da empresa encaixam-se nas cadeias de valor dos fornecedores e clientes.

\subsection{Integração Vertical}

A empresa que integra verticalmente para trás engloba os fornecedores para atuarem dentro de suas atividades, passando dessa forma a produzir os insumos e a comercializá-los. Dessa forma, aumenta volume fabricado e gera um barateamento 
dos custos, uma vez que não há mais a margem dos intermediários, enfatizando também a diminuição do poder de barganha dos fornecedores.

De acordo com Coughlan (2002):

Considera que as decisões de integração vertical devem estar baseadas economicamente em termos de eficiência, ou seja, devem se concentrar em fatores que aumentem a renda e diminuam os custos ou as despesas gerais.

Em relação aos benefícios que essa estratégia gera, nota-se a redução de custos, melhora na eficiência operacional, proporciona um maior controle sobre os prazos de entrega dos produtos, reduzindo também as incertezas do mercado.

Para Porter (1996), "Integração Vertical é a combinação de processos de produção, distribuição, vendas e/ou outros processos econômicos tecnologicamente distintos dentro das fronteiras de uma mesma empresa".

Diante dos riscos da integração vertical, nota-se a perpetuação de ineficiências, aumento de um risco operacional, perda de acesso a tecnologias oriundas do mercado e uma diminuição de ligações com o mercado externo.

Além disso, há também a integração vertical para a frente, a qual é notório quando as empresas caminham em direção ao mercado de consumo final, oferecendo seus produtos diretamente ao cliente e mantendo relações, que antes não aconteciam.

\subsection{Análise Swot}

Análise Swot é uma ferramenta de identificação e estudo sobre o meio em que a organização se encontra imersa. Nessa perspectiva, são analisadas quatro propriedades (Forças, Oportunidades, Ameaças e Fraquezas) que situam a empresa em relação à concorrência e como ela atua no mercado em geral.

Nessa perspectiva, segundo Kotler (2007):

A análise SWOT é importante para qualquer organização com relação a conhecer o potencial e as ameaças que estão dentro e fora do ambiente da organização. Esta análise é de suma importância no planejamento da empresa auxiliando e colaborando com as decisões a serem tomada pelas organizações. 
Cabe ressaltar que a Análise Swot está intrinsicamente ligada à análise do ambiente em que a organização atua, levando em consideração aspectos internos e externos, que interferem diretamente no dia-a-dia da organização. Dessa forma, de acordo com (Dias, 2003):

Diante do cenário competitivo, percebe-se que ao fazer análise do ambiente e definir suas estratégias empresariais, a organização possivelmente estará à frente de seus concorrentes, pois a mesma terá o conhecimento sobre seus pontos fortes, pontos fracos, oportunidades e ameaças utilizando a ferramenta de análise SWOT, juntamente com sua missão que permite à organização definir melhor suas estratégias.

\subsubsection{Análise do Ambiente Interno}

Para o ramo empresarial, uma boa análise sobre o ambiente interno da empresa provê uma identificação clara das fraquezas e limitações, como também forças e potenciais recursos de vantagem competitiva.

Nessa perspectiva, de acordo com Maximiano (2008), "simultaneamente à análise do ambiente externo deve ocorrer à análise do ambiente interno, que tem como objetivo a identificação dos pontos fortes e fracos da organização".

\subsubsection{Forças e Fraquezas}

Trabalhar os pontos fortes da empresa, a fim de potencializá-los e tornarem os mesmos um diferencial comparado a concorrência é o caminho para a vantagem competitiva sustentável.

Dessa maneira, segundo Rezende (2008), "as forças ou pontos fortes da organização são as variáveis internas e controláveis que propiciam condições favoráveis para a organização em relação ao seu ambiente".

Para Martins (2007):

Considera fraquezas como aspectos mais negativos da empresa em relação ao seu produto, serviço ou unidade de negócios. Devem ser fatores que podem ser controlados pela própria empresa e relevantes para o planejamento estratégico. 
Nesse prisma, o papel da organização é minimizar tais fragilidades empresariais em que a empresa não consegue atuar de forma boa e precisa corrigir para modifica-los.

\subsubsection{Modelo VRIO}

O modelo VRIO é um instrumento para análise de recursos em que são analisados quatro fatores importantes para a verificação de suas competitividades em comparação a outros recursos e organizações. Em relação aos critérios, são Valor, Raridade, Imitabilidade e Organização. Dessa forma é estudado e interpretado para auxiliar no ganho de vantagem competitiva e diferenciação da concorrência.

Segundo Lacerda (2014):

O modelo VRIO, fundamentado na visão baseada em recursos, demonstra quais são as características que os recursos devem possuir, a fim de gerar vantagem competitiva que se tornem ainda mais duradouras e eficazes. As questões propostas desenvolvem análises que visam bloquear ameaças originadas no ambiente externo e permite explorar oportunidades.

Ademais o autor Lacerda (2014) também afirmou que:

Os recursos úteis para formulação de estratégias e criação de valores são aqueles que detêm valores para a empresa. Quando estes pontos são identificados, se tem material para que os gestores analisem e trabalhem uma forma de usá-los a favor do desenvolvimento e evolução da empresa.

Em relação aos critérios para os recursos, nota-se que Valor representa o grau de eficiência e eficácia que a empresa explora tal recurso. Raridade é o quanto o recurso é encontrado no mercado e como é explorado. Imitabilidade representa o quão imitável é o recurso por outras empresas/ grupos de pessoas. Por fim, Organização retrata como a organização organiza e explora seus recursos com o intuito de aperfeiçoar-los. A figura da tabela a seguir representa tais conceitos: 


\begin{tabular}{|c|l|}
\hline VRIO & \multicolumn{1}{c|}{ QUESTÕES CHAVE } \\
\hline Valor & $\begin{array}{l}\text { O recurso permite que a empresa explore uma oportunidade ambiental ou } \\
\text { neutralize uma ameaça? }\end{array}$ \\
\hline Raridade & $\begin{array}{l}\text { Orecurso é controlado atualmente apenas por um pequeno número de empresas } \\
\text { concorrentes? }\end{array}$ \\
\hline Imitabilidade & $\begin{array}{l}\text { As empresas sem o recurso enfrentam uma desvantagem de custo para obtê-lo } \\
\text { ou desenvolvê-lo? }\end{array}$ \\
\hline Organização & $\begin{array}{l}\text { As outras políticas e os procedimentos da empresa estâo organizados para dar } \\
\text { suporte à exploração de seus recursos valiosos, raros e custosos para imitar? }\end{array}$ \\
\hline
\end{tabular}

Figura 6: Modelo VRIO e suas questões chave.

Fonte: Barney e Hesterly (2011).

\begin{tabular}{|c|c|c|c|c|}
\hline \multicolumn{5}{|c|}{ Resumo do Modelo VRIO } \\
\hline Tem VALOR? & $\begin{array}{c}\text { Tem } \\
\text { RARIDADE? }\end{array}$ & $\begin{array}{l}E \text { dificil de } \\
\text { IMITAR? }\end{array}$ & $\begin{array}{c}\text { A empresa tem a } \\
\text { devida } \\
\text { ORGANIZAÇÃOO? }\end{array}$ & $\begin{array}{c}\text { Qual o } \\
\text { RESULTADO? }\end{array}$ \\
\hline NÃO & & & & $\frac{\text { Desvantagem }}{\text { Competitiva }}$ \\
\hline SIM & NÃO & & & $\begin{array}{l}\text { Igualdade } \\
\text { Competitiva }\end{array}$ \\
\hline SIM & SIM & NÃO & & $\begin{array}{c}\text { Vantagem } \\
\text { Competitiva de } \\
\text { curto prazo }\end{array}$ \\
\hline SIM & SIM & SIM & NÃO & $\begin{array}{c}\text { Vantagem } \\
\text { Competitiva } \\
\text { desaproveitada }\end{array}$ \\
\hline SIM & SIM & SIM & SIM & $\begin{array}{c}\text { Vantagem } \\
\text { Competitiva de } \\
\text { Longo prazo }\end{array}$ \\
\hline
\end{tabular}

Figura 7: Proposta de avaliação dos recursos.

Fonte: Empiricus Research.

\subsubsection{Análise do ambiente externo}

Para Bethlem (2009):

O ambiente externo exerce muita influência no desempenho da empresa. Desta forma, a empresa precisa realizar uma análise das ameaças e oportunidades, que só é possível a partir de um conhecimento prévio do ambiente em que ela atua ou deseja atuar. 
Nessa perspectiva, um estudo sobre condições no meio em que a empresa atua é fundamental para um entendimento completo e a partir disso um posicionamento para tomadas de decisão. Em relação a isso, é preciso levar em consideração fatores políticos, econômicos, socioculturais, tecnológicos e da natureza.

Assim, Cobra (2003), cita que:

O ambiente externo envolve uma análise das forças macro ambientais (demográficas, econômicas, tecnológicas, políticas, legais, sociais e culturais) e dos fatores micro ambientais (consumidores, concorrentes, canais de distribuição, fornecedores).

\subsubsection{Oportunidades e Ameaças}

Segundo Rezende (2008), “oportunidades para a organização são as variáveis externas e não controladas, que podem criar as condições favoráveis para a organização, desde que a mesma tenha condições ou interesse de utilizá-las”.

Dessa forma, oportunidades podem ser explorados de forma proveitosa pela empresa se a mesma tiver estrutura e capacidade para tornar tal fato um benefício ao seu favor.

De acordo com Martins (2007), "ameaças são atividades que podem levar a empresa para uma redução de receita ou até mesmo a seu desaparecimento".

Sendo assim, uma ameaça pode ser um caminho destrutivo para uma organização, fazendo com que a mesma perca recursos, dinheiro e poder caso não consiga lidar com o que lhe afeta diretamente.

\subsubsection{5 Forças de Porter}

A teoria das 5 Forças de Porter (1986) estabelece cinco forças competitivas que influenciam a força da competição em determinado setor. Nessa perspectiva, o modelo define a melhor colocação empresarial em seu meio, a fim de influenciar forças ao seu lado e minimizar outras que podem abalar a estrutura da empresa. Tais forças correspondem ao poder de barganha dos fornecedores, poder de barganha dos clientes, ameaça de novos entrantes, ameaça de produtos substitutos e rivalidade entre concorrentes. 
Em relação ao poder de barganha dos fornecedores, Porter (1986) afirma que "um fornecedor que oferece um produto diferenciado não pode ser facilmente descartado, portanto, aumenta o seu poder de barganha”. Nessa perspectiva, notase que um fornecedor detém poder de barganha quando trabalham com produtos e serviços de qualidade e que não são encontrados tão facilmente em produtos substitutos ou preços atrativos que ajudam o comprador.

Poder de barganha dos clientes é observado quando os compradores influenciam no preço final. Isso pode ocorrer a partir do volume de compras, da demanda exigida por preços menores ou por pouca diferenciação sobre as mercadorias que são oferecidas no mercado. Segundo Porter (1986), “ essas forças podem ser maiores ou menores dependendo do poder de barganha que esses compradores detêm".

Já a ameaça de novos entrantes corresponde a empresas que buscam adentrar em novas atividades ou mercados, que antes não faziam, brigando contra barreiras de entrada impostas pelo mercado e por concorrentes. Nessa perspectiva, os novos entrantes caçam uma parcela do Market-Sharepara se desenvolver e apresentar suas propostas. Dessa forma, segundo Porter (1986), “essa força como o grau de competitividade do mercado ou até que ponto as empresas são capazes de entrar nesse mercado e concorrer por clientes".

Quanto a ameaça de produtos substitutos, nota-se que acontece quando um produto ou serviço pode ser adquirido em detrimento de outro. Dessa maneira, Porter (1986), afirma que: “os serviços substitutos limitam o potencial de um setor, a menos que este consiga melhorar a qualidade do produto ou, de alguma forma, através do marketing, estabelecer uma diferenciação”.

Rivalidade entre concorrentes é a disputa entre empresas de um mesmo setor que buscam o apelo do consumidor através de preço, marketing, posições estratégicas, público alvo. Nesse ponto são também analisados e comparados fatores empresariais importantes como lucratividade, índice de crescimento e poderio. Assim:

A rivalidade entre os concorrentes de um mesmo setor demonstra a luta dessas em aumentar seu marketshare e conseguir um melhor faturamento. Geralmente, a disputa é 66 acirrada nos preços, no aumento de serviços oferecidos e no aumento de investimento em marketing, entre outros. (Porter, 1999). 


\section{METODOLOGIA}

Esse capítulo procura esclarecer as decisões que foram fundamentais para a construção do projeto e como a pesquisa foi desenvolvida.

Em relação a esse fato, o capítulo é composto por cinco seções em que a primeira remete o tipo de pesquisa realizado. A segunda e terceira seção, relatam e exemplificam as fontes de informações que foram coletadas, para servir de base para o estudo. A quarta seção é apresentada a maneira como os dados são tratados e analisados. Por fim, a quinta expõe as limitações do estudo e sobre as informações adquiridas.

\subsection{Tipo de Pesquisa}

Para a preparação do trabalho, foi usada a pesquisa descritiva, ou seja, a formulação de um questionário semiaberto com o intuito de colher do entrevistado informações relevantes sobre a empresa Habib’s e o modelo estratégico utilizado no passado e que continua sendo mantido na atualidade, enfatizando o sucesso e pioneirismo dessa tomada de decisão.

Segundo Selltiz (1965), as pesquisas descritivas buscam descrever um fenômeno ou situação em detalhe, especialmente o que está ocorrendo, permitindo abranger, com exatidão, as características de um indivíduo, uma situação, ou um grupo, bem como desvendar a relação entre os eventos.

Além disso, cabe ressaltar que o estudo também é composto por pesquisa bibliográfica, porque é apoiada em recursos como: livros, sites e conteúdos compartilhados abertamente a sociedade. Essa metodologia foi usada para atribuir uma fundamentação e complementação mais consistente ao estudo apresentado, de acordo com Marconi e Lakatos (2009). 


\subsection{Seleção de Sujeitos}

A seleção de sujeitos foi constituída por funcionários da franqueadora e franqueados da marca que trabalham em suas lojas. Ademais, as fontes de informação usadas nesse estudo abrangem, livros, filmes e outros materiais relacionados ao tema de estudo proposto.

A tabela mostra cada um dos entrevistados e suas principais características.

Tabela 1: Perfil dos profissionais entrevistados.

\begin{tabular}{|c|c|c|c|c|}
\hline Nome & Gênero & Idade & Cargo & Tempo de Cargo \\
\hline Patrick Stern & Masculino & 27 & Franqueado & 2 anos \\
\hline Bernard Stern & Masculino & 25 & Franqueado & 2 anos \\
\hline Sergio Mendes & Masculino & 50 & Gestor de Operações & 1 ano \\
\hline Patrícia Borges & Feminino & 45 & Consultora de Campo & 1 ano \\
\hline Alex Sandro & Masculino & 40 & Supervisor de lojas & 5 anos \\
\hline Andreia Ferreira & Feminino & 45 & Auditora Financeira & 20 anos \\
\hline
\end{tabular}

Fonte: Elaborada pelo autor.

\subsection{Coleta de dados}

A coleta de dados foi feita a partir de entrevistas individuais, com quatro funcionários que trabalham na empresa Habib’s e dois diferentes franqueados. $\mathrm{O}$ intuito foi analisar como o Habib’s conseguiu manter a estratégia de preços baixos a um baixo custo e como isso afeta diretamente o franqueado na ponta final.

O roteiro dessas entrevistas foi do tipo semiaberto com o uso de perguntas semiestruturadas para dar uma maior liberdade ao entrevistador. As entrevistas foram realizadas parte de forma presencial e com gravação de áudio e parte por meios virtuais com o uso de aplicativos de mensagens de texto e e-mails.

Além disso, foram coletados dados secundários a partir de notícias que saíram no meio digital e papéis impressos, sites de informações abertos ao público geral e o site da própria empresa, enfatizando a veracidade dos dados. 


\subsection{Tratamento de dados}

Posteriormente a realização das entrevistas e gravação das mesmas, os dados foram transcritos e depois analisados qualitativamente, afim de descrever e interpretar as respostas dos entrevistados.

Nesse prisma, foi também realizada um balanço entre o conteúdo das entrevistas e o referencial teórico estudado.

\subsection{Limitações do método}

A prática do presente projeto possui limitações distintas a sua natureza, pois ao longo do estudo não é possível retrucar todos as questões presentes. Tal fator acontece devido ao limitado conhecimento acerca da empresa e pelo escasso tempo trabalhando no âmbito alimentício.

Consoante Gil (2007), a pesquisa bibliográfica possui limitações onde há a possibilidade de os dados terem sidos arrecadados equivocadamente, gerando o comprometimento da qualidade da pesquisa pois existe a possibilidade da reprodução de equívocos dos autores anteriores.

A pesquisa qualitativa pode ser tendenciosa e a maneira que é interpretada é baseada nas convicções do sujeito que foi entrevistado. É importante salientar que as entrevistas podem ser danificas caso os entrevistados não possuam motivações para responder tais questões, podendo mentir ou enganar o entrevistador. Sendo assim, é necessária a separação de um tempo formidável para a coleta de dados.

Ademais, por abordar apenas uma empresa, existe a limitação onde não se pode generalizar os fatos e resultados, uma vez que tais resultados não podem ser debatidos a outras instituições. Como consequência, o número de entrevistados é baixo se comparar a quantidade de pessoas da empresa.

Finalizando, essas entrevistas analisam e entregam relatos dos entrevistados sendo equiparado com os dados obtidos segundo o próprio site da empresa e outros registros impressos. 


\section{ANÁLISE DE RESULTADOS}

\subsection{Análise Ambiental}

\subsubsection{Análise do Ambiente Interno}

Em relação ambiente interno da companhia, pode-se destacar que há pontos fortes e pontos fracos que afetam diretamente a rotina das operações e do Escritório Central. Nessa perspectiva, são elementos e recursos que precisam ser diagnosticados com o intuito de tornar as forças em vantagem competitiva e minimizar as fraquezas a fim de estanca-las.

\subsubsection{Forças e Fraquezas}

No caso Habib’s, podemos destacar que existem muitas forças que a empresa explora de forma eficiente e que levaram a empresa para o caminho do sucesso. Diante desse fato, nota-se que a formulação das Fábricas Centrais, espalhadas pelo Brasil em locais estratégicos, auxiliam na produção dos insumos que abastecem as lojas, conservam o padrão da rede e facilitam a distribuição para os diferentes estados e municípios do Brasil, fazendo dessa forma que as operações possam ser abastecidas de forma organizada, com produtos padronizados e em perfeito estado para o consumidor final. As fábricas ajudam também no controle sobre as lojas, analisando o mix de compras dos insumos, evitando assim que sejam vendidos produtos não homologados pela franqueadora e que o lojista compre sem ser da produção interna.

Ademais, a capacidade de produção é outro ponto forte da organização. Sendo assim, a empresa consegue oferecer produtos de qualidade a preços abaixo dos concorrentes. Dessa forma, o cliente final percebe um valor grande na marca, uma vez que consegue se alimentar bem, pagando um preço justo. Consequentemente, a empresa se utilizou disso para crescer cada vez mais sua parcela no mercado de 
alimentação rápida e chegar a novos potenciais grupos de consumidores fiéis à marca.

Outra força importante da organização é a composição do Escritório Central, formado por diferentes grupos de pessoas e funções que buscam auxiliar o andamento das lojas, todos os dias. Nesse prisma, são colaboradores que analisam o cotidiano das operações e pontuam conforme o desempenho dos funcionários locais e dos próprios franqueados. Assim, são times compostos por Gestores de Operações, Consultores de Campo, Equipe de Qualidade, Gerentes de Marketing e Treinadores que estão diretamente ligados as lojas em prol de uma melhor experiência de consumo para o consumidor final.

Em relação a isso, a entrevistada Patrícia Borges citou:

Nós do Escritório servimos para facilitar a vida de franqueados e lojistas que estão com alguma dificuldade. Analisamos, de forma coletiva, como solucionar os problemas enfrentados, preparando ações internas e externas e vamos para a luta juntos. Nosso papel é fazer o negócio girar.

Além disso, a grande rede de franqueados da marca também é uma força. Nesse prisma, os operadores e representantes da marca trabalham com o intuito de fortalecer a imagem do Habib's, proporcionar uma boa experiência de consumo ao cliente e lutar pela lucratividade do negócio. Também observa em loja, pontos fortes e pontos fracos, dando feedbacks constantes a franqueadora, conseguindo dessa forma realizar mudanças necessárias em um menor espaço de tempo.

Nesse prisma, o franqueado da marca Bernard Stern disse:

Os franqueados ajudam diretamente a empresa. Seja cuidando da marca dos clientes e da rentabilidade operacional, seja dando feedbacks importantes para a revisão de erros, o mais rápido possível. Precisamos dessa relação de ganha-ganha para ambos saírem satisfeitos. Somente assim, vamos caminhar para frente e brigar com os gigantes do mercado.

Em relação às franquezas, podemos notar que há um déficit no atendimento das lojas. Isso porque, na maioria das vezes, é um serviço que precisa ser veloz e básico para conseguir atender o grande volume de clientes que entram nas lojas todos os dias. Desse modo, não é um atendimento cordial, simpático e que gera uma 
boa experiência de consumo para a freguesia. Assim, perde-se a oportunidade de fidelizar mais clientes e gerar mais tráfego todos os dias.

\subsubsection{Análise VRIO}

Tabela 2: Análise dos recursos empresariais sob a perspectiva da Análise VRIO.

\begin{tabular}{|c|c|c|c|c|}
\hline RECURSOS & VALIOSO? & RARO? & DIFÍCIL DE IMITAR? & ORGANIZAÇÃO? \\
\hline Fábricas Centrais & $\operatorname{Sim}$ & $\operatorname{Sim}$ & $\operatorname{Sim}$ & $\operatorname{Sim}$ \\
\hline Rede de Franqueados & $\mathrm{Sim}$ & $\mathrm{Sim}$ & $\mathrm{Sim}$ & $\mathrm{Sim}$ \\
\hline Escritório Central & $\mathrm{Sim}$ & $\mathrm{Sim}$ & $\mathrm{Não}$ & $\mathrm{Sim}$ \\
\hline $\begin{array}{c}\text { Capacidade de } \\
\text { Produção }\end{array}$ & $\mathrm{Sim}$ & $\mathrm{Sim}$ & $\mathrm{Sim}$ & $\mathrm{Sim}$ \\
\hline
\end{tabular}

Fonte: Elaborada pelo autor.

Com a análise VRIO, pode-se concluir que os recursos utilizados pelo Habib’s estão sendo aproveitados de maneira produtiva e geram benefícios para a organização no setor concorrido em que atua.

Dessa maneira, as Fábricas Centrais, espalhadas pelo Brasil, as quais funcionam como um controle da franqueadora sobre as lojas, servindo também para monitorar a padronização dos produtos e logística de abastecimento para os diferentes lugares do Brasil. Tais fatos concretizam que esse recurso é uma vantagem competitiva sustentável para a empresa e consequentemente ajudam em seu processo de diferenciação dos concorrentes.

Em relação a Rede de Franqueados, pode-se afirmar que é um recurso que gera uma vantagem competitiva sustentável, uma vez que os franqueados auxiliam a franqueadora no processo de expansão da marca, abrindo cada vez mais lojas em locais que antes a empresa não conseguia atender. Além disso, os franqueados ajudam no processo de crescimento contínuo, participando ativamente da tomada de decisão coletiva sobre os próximos passos da empresa e o caminho a ser seguido.

De acordo com o franqueado Patrick Stern:

Os franqueados auxiliam diariamente a franqueadora e solucionar problemas com mais agilidade e transparência. Nós, que estamos na ponta da cadeia junto com o cliente final, vemos de perto o que acontece e como são aceitas as estratégias e posicionamentos da marca. Assim, fica mais fácil de metrificar e repassar tais resultados. 
Diante do Escritório Central, o qual é composto por centenas de pessoas que trabalham diariamente com o intuito de ajudar lojas próprias e franqueados em suas operações. São formados por times de Operações, Marketing, Qualidade, Novos Produtos, Expansão, Financeiro, Logística, Recursos Humanos. Funcionam como uma vantagem competitiva temporária, visto que é uma questão de tempo até outras empresas copiarem e ajustarem seu modelo de apoio as lojas aos seus próprios modelos.

Nessa perspectiva, Alex Sandro afirmou:

O Habib’s hoje da um suporte grande para as lojas próprias e franqueadas. Isso porque, conta com um time grande, de diferentes áreas que são contratadas com o intuito de ajudar e caminhar para frente. Para o que precisarem, eles sabem que podem contar com a gente.

Por fim, a capacidade de produção da empresa é um recurso que representa uma vantagem competitiva sustentável, visto que outras empresas no setor não possuem capacidade de produzir seus próprios insumos em larga escala, na velocidade que o Habib’s consegue entregar e com a qualidade necessária para satisfazer o cliente final.

\subsubsection{Análise Ambiente Externo}

Em relação ambiente externo da empresa, nota-se a existência de aspectos ambientais de natureza social, econômica, política, legal, tecnológica e cultural que podem interferir diretamente no dia-a-dia do Habib’s. Nesse prisma, é fundamental um entendimento do contexto espacial e histórico na atuação da empresa para melhor compreensão do todo.

\subsubsection{Oportunidades e Ameaças}

Diante das oportunidades, o Habib’́s atua de forma agressiva e expansionista. Em relação a esse fato, a rede de restaurantes cresce cada vez a partir do sistema de franquias, alinhando-se a novos franqueados operadores que tocam diariamente o andamento das lojas e reportam as notícias. Dessa forma a franqueadora consegue 
capilarizar mais a marca, atingindo novos fregueses e mercados que antes não conseguiam chegar.

Nesse âmbito, de acordo com o franqueado da marca Patrick Stern:

Hoje o Habib’s pode expandir para aonde não conseguia no passado. Abriram lojas em conjunto de franqueados-operadores, que tocam o cotidiano das operações e reportam resultados e problemas a franqueadora. Assim, puderam abraçar diferentes mercados, ir para cidades menores e mais distantes, crescendo como marca e fazendo com que mais pessoas pudessem ir as lojas e conhecer a marca.

Outra oportunidade da empresa é realizar um sistema de marketing mais intenso. Nessa perspectiva, nota-se que o Habib’s pode realizar propagandas mais efetivas e diretas aos seus diferentes compradores, estando mais presente em locais de grande circulação de pessoas e comprando mais espaço na televisão aberta. Dessa maneira, a empresa consegue atingir uma massa volumosa de pessoas em um curto espaço de tempo.

Em relação à ameaça, podemos destacar a competitividade com grandes empresas multinacionais no setor, as quais possuem um poder de investimento e força de marca muito maior do que a empresa brasileira. Nesse prisma, o Mc Donald’s e o Burger King se destacam pelo volume de vendas, tração do cliente e força de marketing, pontos em que o Habib’s não consegue acompanhar.

\subsubsection{As 5 Forças de Porter}

A partir do conceito das 5 forças de Porter, nota-se que para um alinhamento do plano estratégico com o sucesso empresarial no setor alimentício é preciso um entendimento completo do ambiente externo a fim de ganhar uma parcela do mercado e se diferenciar dos concorrentes.

Em relação à rivalidade entre concorrentes, podemos analisar que o mercado brasileiro de alimentação rápida é composto por grandes empresas que possuem uma parte significativa do Market-Share. Nessa disputa, compete-se pelo cliente por meio de propaganda em massa nos meios de comunicação, por preços cada vez mais baratos e novidades que encantam os consumidores e despertam sua 
curiosidade. Assim, o Habib’s atua em paralelo aos gigantes do setor, caminhando para buscar mais espaço.

Nesse prisma, o entrevistado Sergio Mendes, Gestor de Operações da marca citou:

Estamos vivenciando a Guerra dos hamburgueres, aonde as multinacionais lutam para conquistar o cliente oferecendo o preço mais baixo possível. Mas eles estão esquecendo de nós, viemos para brigar de igual a igual, jogando os preços mais pra baixo e espalhando isso na mídia.

Diante do poder de negociação dos fornecedores, a empresa Habib's consegue praticar uma tática que é essencial para o seu sucesso. Em relação a esse fato, a organização negocia, apenas uma vez ao ano, para todas as 14 fábricas centrais que abastecem todo Brasil, com os grandes fornecedores de matéria-prima para serem entregues ao longo do ano. Dessa maneira, a empresa consegue preços de compra muito abaixo do mercado em geral, por conta do grande volume negociado. Assim, o Habib’s consegue manter o preço dos seus produtos mais baratos do que a concorrência e conservar o preço da esfiha, por muitos anos, abaixo de $\mathrm{R} \$ 0,99$, mesmo levando em conta a inflação neste período.

No que diz respeito a produtos substitutos, pode-se destacar que a empresa sofre com constantes "plágios" de outras instituições que tentam copiar e vender o principal produto da rede: a esfiha. Entretanto, por possuir o controle sobre a fabricação dos insumos e uma grande escala de compras, a empresa consegue efetuar preços que outras empresas não podem igualar.

Sobre a ameaça de novos entrantes, observa-se que há poucas empresas no mercado alimentício de comida rápida que dominam grande parte do mercado. Sendo assim, são redes que possuem um número grande de estabelecimentos comerciais e estão consolidadas. Nesse prisma, para um novo player entrar nesse ramo se faz necessário um enorme investimento de capital e trabalho com o intuito de adquirir seu próprio público fiel, uma vez que as outras empresas já possuem isto há anos.

Por fim, em relação ao poder de negociação dos clientes, nota-se que o preço é o principal diferencial no vínculo de barganha dos clientes. Entretanto, caso o consumidor não esteja satisfeito com o serviço, produto ou preço, ele opta pela 
concorrência em outra oportunidade. Desse modo, é imprescindível prezar pelo bom atendimento e oferecer um produto a um baixo custo.

\subsection{Estratégia de Liderança de Custo e Integração Vertical}

O Habib’s cresceu e se desenvolveu como marca por conta da utilização e execução, de maneira bem-feita, da estratégia de liderança de custo. Em relação a esse fato, a organização conseguiu entrar no mercado alimentício de comida rápida e se estabeleceu com a proposta de ser uma rede de comida barata e de qualidade. Nessa perspectiva, a empresa ofereceu no passado e ainda oferta hoje, promoções que são mais atrativas financeiramente comparado aos seus concorrentes. Dessa maneira, capta mais clientes que são sensíveis ao preço, ganhando assim mais parcela do mercado.

No intuito de servir um produto de qualidade, mantendo o preço bem acessível, foi necessária uma visão detalhista, da empresa e do fundador, nos custos de produção. Para tal, a organização verticalizou para trás grande parte da cadeia produtiva, criando dessa forma 14 fábricas industriais espalhadas pelo Brasil, em locais estratégicos (um raio de até 350 quilômetros dos pontos de vendas que são abastecidos), aonde são fabricados e distribuídos a maioria dos itens comercializados dentro de loja, mantendo qualidade máxima e padrão.

De acordo com Patrick Stern:

As criações das Fábricas Centrais tiveram um papel muito importante para a sustentação do crescimento da rede e como a franqueadora conseguiu se desenvolver. As mesmas serviam, e ainda servem, como a principal ferramenta de controle sobre o padrão dos produtos e logística integrada para as diferentes cidades.

Nesse âmbito, a primeira fábrica central foi inaugurada em 1991 com o intuito de abastecer as 16 lojas da rede até então e facilitar a distribuição dos produtos, garantindo consequentemente um controle maior sobre as lojas, padrão e qualidade. Entretanto, o que os diretores da marca não sabiam é que o efeito dessa tomada de decisão seria imprescindível para o sucesso da franqueadora e seu crescimento exponencial ao longo dos anos. 


\section{Segundo a entrevistada Andreia Ferreira:}

Cheguei na empresa e a fábrica já existia há alguns anos. Era magnífica. Um espaço enorme, lotado de gente que produzia muito para atender todas as lojas. Foi uma grande ideia, pois gerou tudo que a rede precisava naquele momento e para os anos seguintes: produção em larga escala e padronizada, controle, logística e abastecimento contínuo.

Hoje, a empresa conta com unidades fabris de Pães (Arabian Bread). Propaganda e Marketing (PPM), Laticínios (Promilat), a Sorvetes (Ice Lips e Portofino), Central de Atendimento por telefone (Voxline), a qual tira as dúvidas, ouve opiniões e oferece atenção aos clientes, Engenharia e novos projetos (Vector 7), Consultoria imobiliária (Plannej), Franquia (Franconsult) e uma agência de turismo (Bib’sTur), como podemos ver na figura abaixo:

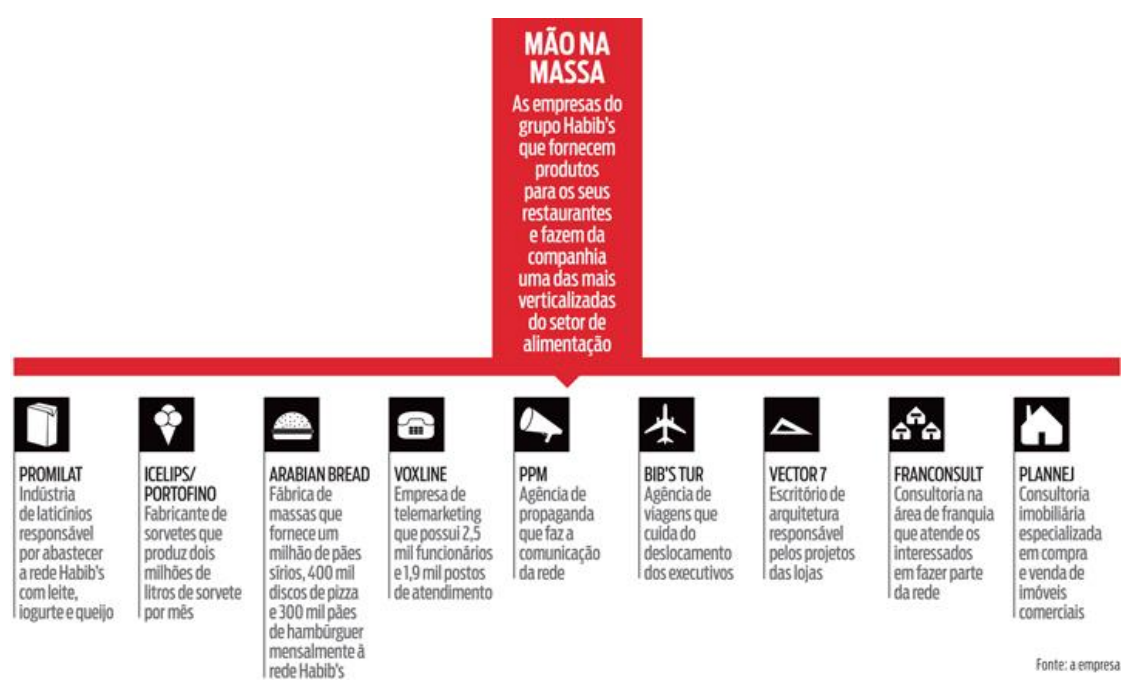

Figura 8: Estrutura verticalizada da empresa e características.

Fonte: Empresa Habib’s.

Assim, o franqueado da marca Bernard Stern afirma:

As empresas formadas pelo grupo auxiliam na manutenção de custo e como podem produzir mais utilizando menos recursos, em áreas difertentes. Eles executaram essa estratégia para competir contra as grandes redes mundiais.

Como resultado, a empresa chegou a impressionante marca de comercializar mais de 9 bilhões de "Bib'sfihas", sendo 680 milhões, aproximadamente, vendidas anualmente, nesses últimos 3 anos. Se comparado ao ano de 1991, quando eram vendidas menos de 1 milhão de esfihas por ano, o crescimento é enorme. 
Nesse prisma, segundo Andreia Ferreira:

O Habib's cresceu absurdamente em um curto espaço de tempo. Conforme o tempo passava e novas lojas eram inauguradas, cada vez mais eram vendidos os produtos como esfiha e kibe e mais o nome da marca estava na boca do povo.

Além disso, a empresa bateu a marca de 22 mil colaboradores, atuando nas diferentes empresas da corporação. No ano de 1991, eram menos de 500 pessoas trabalhando nas 16 lojas e na fábrica recém montada. Hoje, a empresa conta com 543 restaurantes, pertencente parte a própria franqueadora e parte para franqueados.

Assim, o Habib's se vangloria de ser a maior rede de culinária arábe do mundo, sendo considerada a terceira melhor rede de fast-food no Brasil, de acordo com pesquisas feitas pelo Food Consulting.

\subsection{Planos para o futuro}

Para os próximos anos a empresa é otimista e projeta crescimento no número de lojas, clientes atendidos e de faturamento. Em 2019, a meta do Habib's era inaugurar mais 120 lojas, totalizando dessa forma 660 lojas da rede, e tal plano irá se concretizar.

Além disso, a organização aposta no consumo em que a venda é feita fora da loja, seja Delivery, o qual a venda é para ser entregue na casa do cliente. Como também, o sistema "pick-up", no qual o cliente retira seu pedido na loja para consumir em casa. Nessa perspectiva, tais meios de venda representavam 17\% do total de vendas, há dois anos e hoje já superam os 45\%, de acordo com Habib’s (2019). 
Assim, o supervisor de lojas Alex Sandro citou:

O Habib's sabe que com a chegada dos novos aplicativos, do novo serviço de entrega e a falta de segurança no Brasil, as pessoas vão cada vez mais deixar de sair para comer e pedir mais em casa. Vamos entrar com tudo nesse meio de venda para faturar.

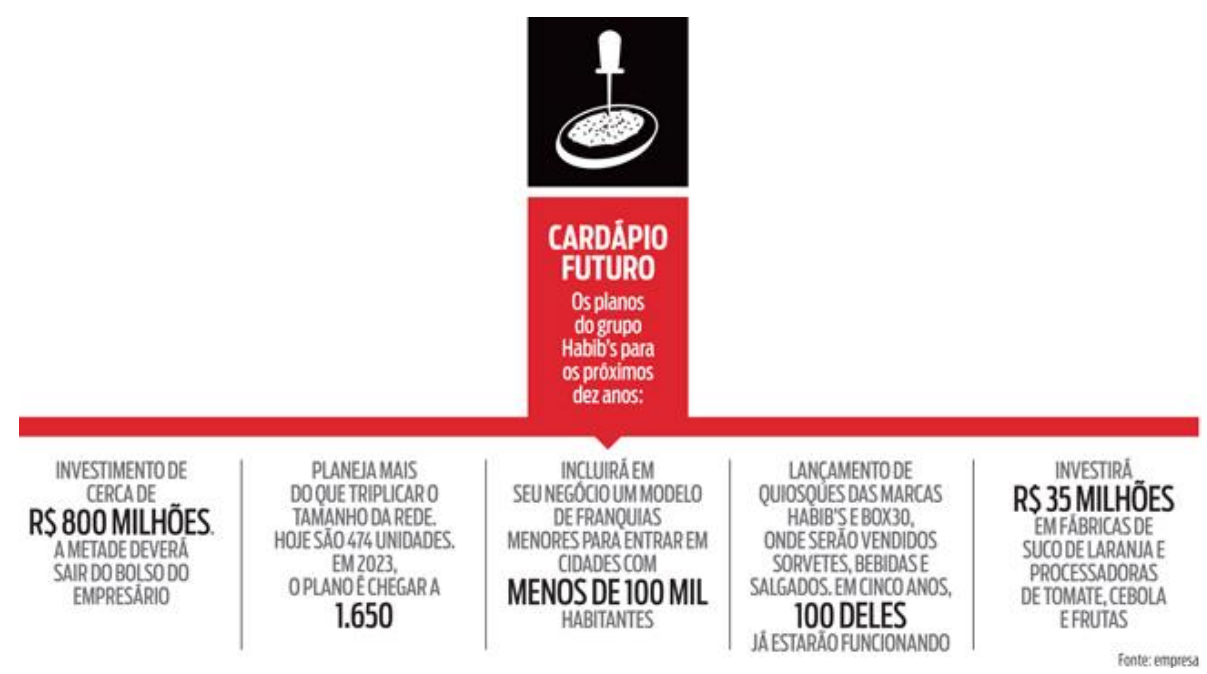

Figura 9: Próximos passos da organização.

Fonte: Empresa Habib’s. 


\section{CONCLUSÃO}

A partir do conteúdo apresentado, das entrevistas realizadas e de outros estudos feitos, foi possível compreender mais como a estratégia de liderança de custo e o processo de verticalização tornaram o Habib’s a grande potência do mercado alimentício brasileiro que é hoje. Nesse âmbito, concluiu-se que tais tomadas de decisões mudaram a trajetória da organização e a fizeram caminhar para o sucesso.

Com o intuito de aprofundar a análise, foi usado como referência a perspectiva de Porter e outros autores sobre Tripologia de Porter, o qual foi essencial para entendimento da liderança em custo e como a empresa efetuou essa estratégia. Além disso, foi utilizado também, conceitos sobre integração vertical para o entendimento de como a empresa conseguiu atingir a estratégia anterior.

Evidencia-se, portanto, que a empresa conseguiu no passado e mantem na atualidade uma boa execução da estratégia traçada, desde a década de 90, construindo grande fábricas e diversificando o portifólio de empresas produtoras de insumos que funcionam para o abastecimento da rede. Assim, o Habib's consegue manter os preços justos e produtos de qualidade, que encantam o cliente e os fazem retorna para consumir novamente em um curto espaço de tempo.

Ademais, a diversificação irá trazer benefícios, pois agregará valor a instituição e os clientes perceberão mais valor na marca, trazendo dessa forma mais visibilidade e um maior ganho na parcela de mercado, em detrimento dos seus concorrentes.

\subsection{Sugestões e recomendações para novos estudos}

Este projeto pretendeu investigar como a empresa Habib's conseguiu manter sua estratégia de liderança de custo ao longo do tempo, e o cerne do conteúdo foi o processo de integração vertical realizado pela organização. Dessa maneira, outros projetos que analisem como essa estratégia pode gerar benefícios são oportunos. 
Outros estudos que se mostram pertinentes como legado de empresas que executaram de maneira bem-feita suas estratégias de liderança de custo são: Gol Linhas Aéreas e Hotéis Íbis, concretizando assim bons comparativos e maior uso de dados analíticos. 


\section{REFERÊNCIAS BIBLIOGRÁFICAS}

BARNEY, J. B.; HESTERLY, W. S. Administração estratégica e vantagem competitiva. São Paulo: Pearson Prentice Hall, p. 66-67, 2009.

BENNETT, P.D. Dictionary of Marketing Terms. 2 aed., Chicago: American Marketing Association, p. 74-79, 1995.

BETHLEM, A. Estratégia empresarial: conceitos, processos e administração estratégica. $6^{a}$ ed., São Paulo: Atlas, p. 42-51, 2009.

COBRA, Marcos. Consultoria em Marketing Manual do Consultor. $1^{a}$ ed., São Paulo: Cobra Editora e Marketing, p. 74-79, 2003.

COUGHLAN, A. T. et al., Canais de marketing e distribuição. $6^{a}$ ed., Porto Alegre: Bookman, p. 74-78, 2002.

DAFT, R. Organizações: Teoria e projeto. São Paulo: Cengage Learning, p. 85-98, 2003.

DIAS, S. R. (Coord). Gestão de Marketing.São Paulo: Saraiva, p. 85-94, 2003.

HANSE, Don et al., Gestão de Custos: Contabilidade e controle. São Paulo: Pioneira Thomson Leraning, p. 55-58, 2001.

HITT, M. A. et al. Strategic management. Cincinnati: South Western College. p. 15-47,1999.

KOTler, P.; ARMSTRONG, G. Princípios de Marketing. (Trad.). YAMAGAMI, Cristina. 12a ed., São Paulo: Pearson Prentice Hall, p. 47-59, 2007.

; KELLER, K. L. Administração de Marketing. São Paulo: Pearson, p. 56-68, 2007.

LACERDA, Daniel P. et al., Estratégia Baseada em Recursos: 15 Artigos Clássicos para Sustentar Vantagens Competitivas. $1^{a}$ ed., Porto Alegre: Bookman, p. 75-81, 2014.

LIU, M. et al.Breakfast, lunch, and dinner expenditures away from home in the United States.Food Policy, v. 38, p. 156-164, 2013. 
MARTINS, Marcos Amâncio P. Gestão Educacional: planejamento estratégico e marketing. $1^{a}$ ed., Rio de Janeiro: Brasport, p. 56-64, 2007.

MAXIMIANO, A. C. A. Teoria geral da administração: da revolução urbana à revolução digital. $6^{a}$ ed., São Paulo: Atlas, p. 74-78, 2008.

PISCOPO, M. R.; OLIVEIRA JÚNIOR, M. M. O Dilema Custos versus Diferenciação. Disponível em: XXXXX. Acesso em: 20 abr. 2006.

PORTER, M. E.Competitive advantage: creating and sustaining competitive performance. New York: Free Press, p. 55-58, 1985.

Estratégia Competitiva: técnicas para análise de indústria e da concorrência. (Trad.). BRAGA, Elizabeth Maria de Pinho. $2^{\mathrm{a}}$ ed., Rio de Janeiro: Elsevier, p. 85-86, 2004.

. The competitive advantage of nations.Harvard Business Review, p.7393, Mar./Apr, p. 82-92, 1990.

. Towards a dynamic theory of strategy.Strategic Management Journal, v.12, p.95-117, 1991.

What is strategy? Harvard Business Review, p. 61-78, Nov./Dec. 1996.

REZENDE, Denis Alcides. Planejamento Estratégico para Organizações: públicas e privadas. $1^{\text {a }}$ ed., Rio de Janeiro: Brasport, p. 63-65, 2008.

RIBEIRO, F. C. F. et al., O dilema custos versus diferenciação: Um estudo de casa na Companhia Siderúrgica Nacional. In: Anais do XXVIII Encontro da ANPAD - CD, p. 58-62, 2003.

SHANK, J.; GOVINDARAJAN, V. A Revolução dos Custos: Como Reinventar e Redefinir sua Estratégia de Custos para Vencer em Mercados Crescentemente Competitivos. Editora Campus, Brasil, p. 77-76, 1997.

SILVA, E. M. Alinhamento das estratégias competitivas com as estratégias de produção: Um estudo de caso no pólo moveleiro de Votuporanga - SP. 2003. 163 f. Dissertação (Mestrado em Engenharia de Produção) - USP São Carlos, 2003.

THOMPSON, A. A. et al., Administração estratégica. $15^{\text {a }}$ ed., São Paulo: McGraw-Hill, p. 36-39, 2008. 


\section{ANEXO 1: ROTEIRO PARA AS ENTREVISTAS}

\section{QUESTIONÁRIO}

1- Qual a missão e visão do Habib's? A empresa vem agindo conforme sua missão e visão, em prol de conseguir concretizar seus objetivos? Como?

2- Como o senhor enxerga, de maneira geral, a estratégia do Habib's?

3- Na sua opinião, quais são os pontos favoráveis, praticados pelo Habib's, para a obtenção de vantagem competitiva?

4- Para o senhor(a), quais são as ameaças e oportunidades externas que existem para a empresa e como isso pode afetar a formulação da estratégia da marca?

5- Para o senhor(a), quais são as forças e fraquezas internas que existem para a empresa e como isso pode afetar a formulação da estratégia da marca?

6- Em relação a estratégia de corporativa, como a empresa consegue manter preços tão baixos ao longo do tempo, levando em conta a inflação?

7- Como o Habib's consegue desenvolver uma estratégia de negócios focada em franquias sem perder qualidade, padrão e a essência da marca? 
8- Como foi o desenvolvimento da integração vertical para trás na empresa, época em que o Habib's começou a produzir seus próprios insumos? Como foi planejado, desenvolvido e executado?

9- Quais são os próximos passos da franqueadora e o que esperar da marca? 